\title{
The TI799A point mutation is present in posterior uveal melanoma
}

\author{
CS Janssen', R Sibbett ${ }^{2}$, FL Henriquez ${ }^{3}$, IC McKay ${ }^{4}$, EG Kemp ${ }^{5}$ and F Roberts*,2 \\ 'Division of Infection \& Immunity, FBLS, University of Glasgow, Glasgow, UK; ${ }^{2}$ Department of Pathology, Western Infirmary, Glasgow, UK; ${ }^{3}$ School of \\ Engineering and Science, University of the West of Scotland, Paisley, UK; ${ }^{4}$ Sherbrooke Consultants, 22 Sherbrooke Drive, Glasgow, UK; ${ }^{5}$ Tennent Institute \\ of Ophthalmology, Gartnavel General Hospital, Glasgow, UK
}

\begin{abstract}
An activating mutation in exon 15 of the BRAF gene is present in a high proportion of cutaneous pigmented lesions. Until recently this mutation had however only been identified in one case of posterior uveal melanoma. Despite this apparent lack of the BRAF mutation, inappropriate downstream activation of the Ras/Raf/MAPK pathway has been described in posterior uveal melanoma. Based on the already recognised morphological and cytogenetic heterogeneity in uveal melanoma, we hypothesised that the BRAF mutation may be present in uveal melanoma but only in some of the tumour cells. In this study, we analysed 20 ciliary body and 30 choroidal melanomas using a nested PCR-based technique resulting in the amplification of a nested product only if the mutation was present. This sensitive technique can identify mutated DNA in the presence of wild-type DNA. The mutation was identified in 4 of 20 (20\%) ciliary body and II of 30 (40\%) choroidal melanomas. Further analysis of separate areas within the same choroidal melanoma demonstrated that the mutation was not present in the entire tumour. In conclusion, the TI799A BRAF mutation is present in a proportion of posterior uveal melanomas but within these tumours the distribution of the mutation is heterogeneous. British Journal of Cancer (2008) 99, 1673- 1677. doi:| 0.1038/sj.bjc.660473 I www.bjcancer.com
\end{abstract}

Published online 4 November 2008

(c) 2008 Cancer Research UK

Keywords: melanoma; choroid; ciliary body; cytogenetic; heterogeneity; BRAF gene

Mutations in the BRAF gene (a member of the Raf family that encodes a serine/threonine protein kinase) have been shown to occur in the majority of cutaneous melanomas (Brose et al, 2002; Davies et al, 2002). In particular a single point mutation in exon 15 (T1799A), which results in constitutive kinase activity and unregulated signal transduction, is involved in up to $80 \%$ of cases (Brose et al, 2002; Davies et al, 2002). Despite the high incidence of this mutation in cutaneous melanoma, several studies have shown that it is not present in posterior uveal melanoma (Cohen et al, 2003; Weber et al, 2003). The BRAF mutation has however been identified in several primary uveal melanoma cell lines and recently Malaponte et al (2006) identified the mutation in one primary uveal melanoma. Recently, we have identified that the mutation also occurs in iris melanoma (Henriquez et al, 2007). The reason for this discrepancy in reporting of the BRAF mutation is not clear. Cutaneous and uveal melanoma share a common embryological origin from cells of the neural crest and often exhibit similar histological characteristics (Hogan et al, 1971). However, it is well-recognised that individual uveal melanomas display considerable morphological and cytogenetic heterogeneity (COMS, 1998; Sandinha et al, 2006; Maat et al, 2007). To date the methods used to identify the BRAF mutation have not taken this potential genetic heterogeneity into account. The negative results from previous studies may reflect the inability of the technique

\footnotetext{
*Correspondence: Dr F Roberts, University Department of Pathology, Western Infirmary, Dumbarton Road, Glasgow, GII 6NT, UK. E-mail: fiona.roberts@northglasgow.scot.nhs.uk

Revised 27 June 2008; accepted 22 September 2008; published online 4 November 2008
}

used to identify the mutation in a minority of cells in a background of cells containing the wild-type BRAF gene.

To address this problem we used a nested PCR-based technique, which would result in the amplification of a nested product only if the mutation was present. This technique was used to screen posterior uveal melanoma samples for the presence of the BRAF mutation and secondly to examine separate areas within individual tumours to confirm genetic heterogeneity.

\section{MATERIALS AND METHODS}

\section{Case selection}

Archival formalin- or gluteraldehyde-fixed, paraffin-embedded tissue sections from choroidal and ciliary body melanomas were retrieved from the Eye Pathology Files, Western Infirmary Glasgow. Clinical and histological details (such as age, sex, metastasis, largest basal dimension of tumour, cell types, presence of closed vascular loops) were obtained from the pathology report. A total of 30 choroidal melanomas and 20 ciliary body melanomas were selected for this study. This project received the full approval of the West Ethics Committee, North Glasgow Hospitals, and adhered to the tenets of The Declaration of Helsinki. Normal tissue adjacent to the tumour was used as a negative control. The SKmel-28 cell line was used as a positive control. Human foreskin fibroblasts (HFF) were used as a negative control for developing the technique.

\section{Genomic DNA isolation}

One unmounted haematoxylin and eosin- (H\&E) stained $4 \mu \mathrm{m}$ section was examined from each case and appropriate areas of 
tumour and normal tissue identified. A $15 \mu$ l droplet of proteinase $\mathrm{K}$ ( $1 \%$ solution in $10 \mathrm{~mm}$ Tris ( $\mathrm{pH} 8.5$ ) and $1 \mathrm{~mm}$ EDTA) was added to the relevant areas on the section and the cells scraped with a fresh scalpel blade until suspended in the droplet. The solution was then pipetted into a $0.2 \mathrm{ml}$ PCR tube. The samples were incubated at $55^{\circ} \mathrm{C}$ for $20 \mathrm{~h}$. Following the addition of $15 \mathrm{ml}$ of water, proteinase $\mathrm{K}$ was inactivated by incubation at $95^{\circ} \mathrm{C}$ for $8 \mathrm{~min}$. The isolated DNA was stored at $4^{\circ} \mathrm{C}$ until further use in PCR. For all choroidal and ciliary body melanomas one area of tumour was sampled for investigation. To investigate heterogeneity within the tumour additional areas of tumour were sampled from 12 of the choroidal melanoma cases.

For control DNA SKmel-28 and HFF cells were harvested and pelleted by centrifugation at $1500 \mathrm{~g}, 4^{\circ} \mathrm{C}$, for $10 \mathrm{~min}$, and washed with PBS. The cells were incubated for $3 \mathrm{~h}$ at $50^{\circ} \mathrm{C}$ in 1 volume lysis solution, (100 mM Tris $\mathrm{pH} 7.4,100 \mathrm{~mm}$ EDTA $\mathrm{pH} 8.0,1 \%$ SDS, $1 \mathrm{mg} \mathrm{ml}^{-1}$ proteinase $\left.\mathrm{K}\right)$. The lysate was treated by phenol and chloroform extraction, and the aqueous layer centrifuged at $12000 \mathrm{~g}$ for $15 \mathrm{~min}$ at $4{ }^{\circ} \mathrm{C}$. After isopropanol/ $/ 0.2 \mathrm{M} \mathrm{NaCl}$ precipitation at room temperature for $10 \mathrm{~min}$, the sample was centrifuged at $12000 \mathrm{~g}$ for $10 \mathrm{~min}$ at $4^{\circ} \mathrm{C}$. Pellets were washed three times with $75 \%$ ethanol, air dried, and dissolved in $\mathrm{H}_{2} \mathrm{O}$.

\section{Polymerase chain reaction}

Primary PCR Primary PCR amplification reactions were performed in a $25 \mu \mathrm{l}$ reaction using ReddyMix (ABgene, Epson, UK) containing 5 pmol of forward ( $5^{\prime}$-TCATAATGCTTGCTCTGATA GGA- $\left.3^{\prime}\right)$ and reverse (5'-GGCCAAAAATTTAATCAGTGGA- $\left.3^{\prime}\right)$ primer and $5 \mu \mathrm{l}$ of gDNA template isolated from tumour cells. Reactions consisted of an initial denaturation at $95^{\circ} \mathrm{C}$ for $3 \mathrm{~min}$ followed by 28 cycles of denaturation at $95^{\circ} \mathrm{C}$ for $20 \mathrm{~s}$, annealing for $30 \mathrm{~s}$ at $55^{\circ} \mathrm{C}$ and extension at $72^{\circ} \mathrm{C}$ for $45 \mathrm{~s}$. A final extension was carried out at $72^{\circ} \mathrm{C}$ for $10 \mathrm{~min}$. Three reactions were carried out per DNA extraction.

Secondary PCR Secondary PCRs were performed in a $20 \mu$ l reaction using ReddyMix (ABgene) containing $5 \mathrm{pmol}$ of mutation-specific forward (5'-GATTTTGGTCTAGCTACACA- $\left.3^{\prime}\right)$ primer, which was optimised to anneal only at the mutation site, if present. Also included were 5 pmol of wild-type forward primer $\left(5^{\prime}\right.$-GCTCTGATAGGAAAA TGAGATC- $\left.3^{\prime}\right)$ and reverse primer $\left(5^{\prime}\right.$-GTGGAAAAATAGCCTCAA TTC- $3^{\prime}$ ), with $2 \mu \mathrm{l}$ of template from the primary PCR. Reactions consisted of an initial denaturation at $95^{\circ} \mathrm{C}$ for $3 \mathrm{~min}$ followed by 35 cycles of denaturation at $95^{\circ} \mathrm{C}$ for $20 \mathrm{~s}$, annealing for $30 \mathrm{~s}$ at $50^{\circ} \mathrm{C}$ and extension at $72^{\circ} \mathrm{C}$ for $45 \mathrm{~s}$. A final extension was carried out at $72^{\circ} \mathrm{C}$ for $10 \mathrm{~min}$. All reactions were carried out in triplicate.

\section{Polyacrylamide Gel Electrophoresis}

Precast polyacrylamide gels (6\%) (Invitrogen, Paisley, UK) were immersed in TBE buffer. Samples were loaded on to the gel and electrophoresed for $1 \mathrm{~h}$ at $100 \mathrm{~V}$.

\section{Silver staining}

Following electrophoresis the gels were immersed in fixing solution ( $10 \%$ ethanol, $0.007 \%$ acetic acid) for $5 \mathrm{~min}$. A further $50 \mathrm{ml}$ of fixing solution containing $0.2 \mathrm{~g}$ silver nitrate was added, and gels stained for $10 \mathrm{~min}$. Gels were washed two times in de-ionised water for $20 \mathrm{~s}$ and $1 \mathrm{~min}$, respectively. The gel was developed by immersing it immediately in $150 \mathrm{ml}$ of $0.75 \mathrm{M} \mathrm{NaOH}$ containing $0.007 \%$ formaldehyde until bands appeared. Finally, the gel was rinsed in de-ionised water and washed two times in fixing solution. A band of 200 nucleotides (nt) was obtained in each sample representing the wild-type gene. A further band at $100 \mathrm{nt}$ was present in cases that contained the T1799A mutation. When the wild-type reverse primer was used the second band was approximately $140 \mathrm{nt}$. In addition, in reactions from DNA extracted from archival paraffin-embedded sections, occasional additional bands were present. This artefact was considered unavoidable as DNA extracted from the paraffin tissue is highly fragmented, and some of the small fragments can lead to selfpriming within the reaction.

\section{Statistical analysis}

For choroidal melanoma the relationship of known survival time with $B R A F$ mutation, sex, cell type and vascular loops was tested one at a time by a Kaplan-Meier analysis and the relationship of survival time with age and tumour diameter were tested using the 'Regression with Life Data' function of Minitab 13.1 (Minitab Inc., State College, PA, USA). The relationship between known survival time and the other variables was also considered in a single multivariate survival analysis. When several tumour areas were sampled from a single tumour association with cell type were assessed by Fisher's exact test.

It was not possible to do this analysis for ciliary body melanoma due to the smaller number of cases and absence of survival data. The relationship between age and the presence of the BRAF mutation was assessed by a two-tailed 2 -sample $t$-test.

\section{RESULTS}

\section{SKmel-28 and HFF}

Positive and negative $B R A F$ mutation controls were used to ensure the optimisation of the method. Two products of 200 and 100 base pairs (bp) were obtained for SK-mel28, which contains the T1799A $B R A F$ mutation and one product of $100 \mathrm{bp}$ for HFF negative control (Figure 1). Identical results were obtained in replicate experiments including titration and kinetic analysis, covering 36 replicates (see Figure 1) Mixing DNA from SKmel-28 and HFF showed that the second $(100 \mathrm{bp})$ band, indicating the presence of the mutation, could still be identified in addition to the wild-type

A

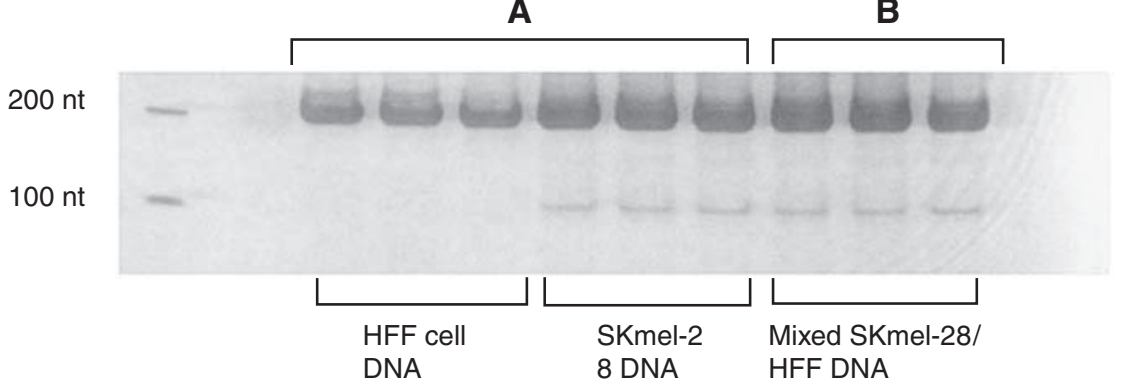

Figure I Silver-stained polyacrylamide gel showing a single band at $200 \mathrm{nt}$ for human foreskin fibroblast (HFF) DNA (A) and an additional band at I00 nt for SKmel-28 cell DNA (A). Mixed DNA from HFF and SKmel-28 (B) also shows molecular markers at 200 and I00 bp respectively. 
product of $200 \mathrm{bp}$ (Figure 1), when sampling a mixture of one SKmel-28 cell in 100 HFF cells.

\section{Choroidal and ciliary body melanomas}

The T1799A mutation was identified in 4 of the 20 ciliary body melanomas studied and in 11 of the 30 choroidal melanomas examined.

In addition, sampling of several different areas was undertaken in the 11 positive cases of the choroidal melanoma cases to investigate potential heterogeneity of the T1799A mutation within the tumour sample. Between three and six areas were sampled depending on tumour size (Figure 2; Table 1). Five of the 11 cases contained the BRAF mutation in all areas sampled. In four out of the 11 cases the mutation was present in one sampled area only. In two cases the mutation was present in two sampled areas.

\section{Clinical and pathological details}

\section{Ciliary body}

BRAF-positive cases: Of the four positive cases out of 20 there were three enucleation specimens and one local resection specimen from two men and two women with an average age of 33.5 years (range, 16 to 48 years). Two of the four patients were alive and well, one had died from an unrelated cause. We were unable to obtain clinical follow up information on the fourth patient. The pathology report and original sections were available for review in all cases. The average largest dimension of the tumour was $15.5 \mathrm{~mm}$ (range, $10-20 \mathrm{~mm}$ ). Three tumours were composed of spindle cells and one was of mixed spindle and epithelioid cells. Three of the tumours contained closed vascular loops.

BRAF negative cases: Of the 16 cases out of 20 negative cases there were eight enucleations and eight local resection specimens from seven men and nine women with an average age of 59.6 years (range, 30-80 years). One patient had died of metastatic disease and six patients were alive and well at last follow up. We were unable to obtain clinical follow up information on the remaining nine patients. The pathology report and original sections were available for review in all cases. The average largest dimension of the tumour was $12.7 \mathrm{~mm}$ (range, 5-22 mm). Seven tumours were composed of spindle cells and nine were mixed spindle and epithelioid cells. Seven tumours contained closed vascular loops.

The clinical and pathological details are summarised in Table 2. There were no convincingly statistically significant associations between the presence of the BRAF mutation and clinical and pathological features.

\section{Choroid}

BRAF-positive cases: Of the 11 positive cases out of 30 there were six enucleations and five local resection specimens from six women and five men with an average age of 51 years (range, 42-69 years). Clinical follow up was available in all cases. Eight of the patients had died from metastatic tumour and three were alive and tumour free at last follow up. The pathology report and original sections were available for review in all cases. The average largest dimension of the tumour was $14.5 \mathrm{~mm}$ (range $10-18 \mathrm{~mm}$ ). Five tumours were composed of spindle cells, one of epithelioid cells and five were mixed spindle and epithelioid cells. Nine tumours contained closed vascular loops.

BRAF-negative cases: Of the 19 positive cases out of the 30 negative cases there were 12 enucleations and seven local resection specimens from 11 women and eight men with an average age of 57.4 years (range, 19-75 years). Clinical follow up was available in all cases. Eight of the patients had died from metastatic tumour and 11 were alive or had died from other causes. The pathology report and original sections were available for review in all cases. The average largest dimension of the tumour was $14.7 \mathrm{~mm}$ (range, $8-23 \mathrm{~mm}$ ). Eleven of the tumours were composed of spindle cells and eight were of mixed spindle and epithelioid cells. Twelve tumours contained closed vascular loops.

The clinical and pathological details are summarised in Table 2. The Kaplan-Meier survival curve for patients with tumours with and without the $B R A F$ mutation is shown in Figure 3. There was a trend for $B R A F$-positive tumours to show a shorter survival but this was not statistically significant. There were no statistically significant associations between any other clinical or pathological characteristics and the presence of the BRAF mutation. Furthermore, in tumours where several areas of the tumour were dissected there was no association between cell type in the individual areas and presence of the mutation.
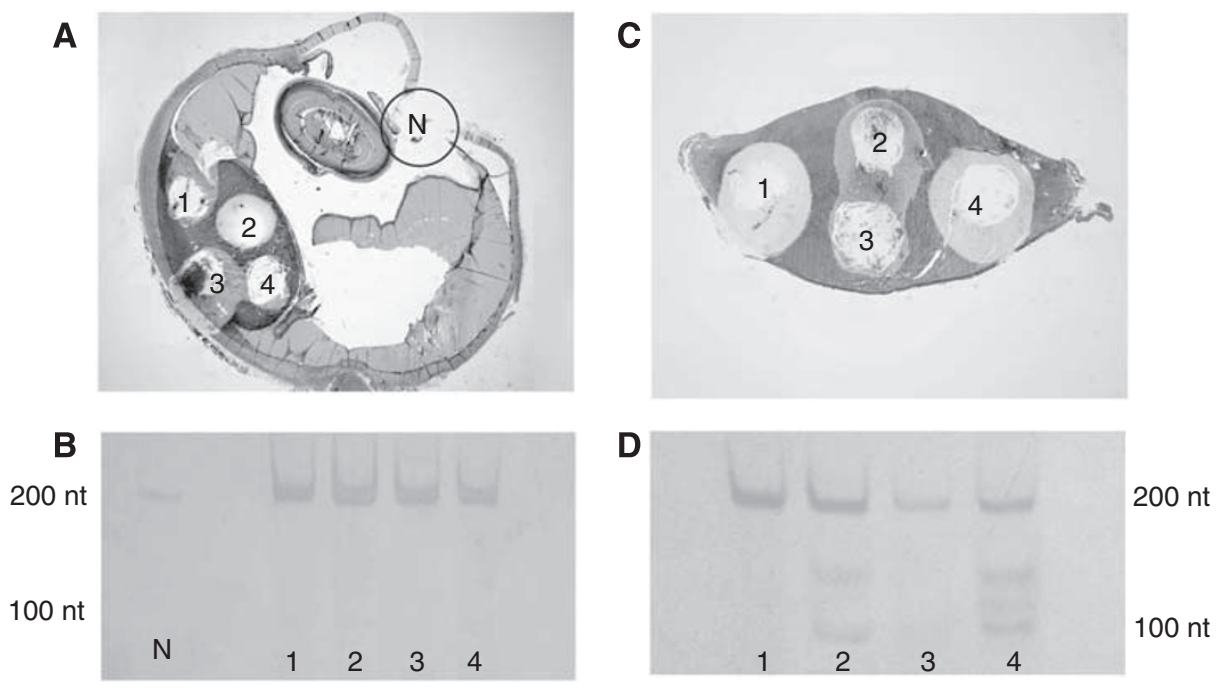

Figure 2 (A) Tissue section of enucleation specimen after dissection of four tumour areas $(\mathrm{I}-4)$ and one normal tissue area ( $\mathrm{N})$. (H\&E, magnification $\times$ 1.25). (B) Silver-stained polyacrylamide gel showing a single band at $200 \mathrm{bp}$ in the four corresponding tumour samples and in the normal tissue sample indicating lack of the TI799A point mutation in this case. (C) Tissue section of local resection specimen after dissection of four tumour areas (I -4). (H\&E, magnification $\times 2$ ). (D) Silver-stained polyacrylamide gel showing an additional band at $100 \mathrm{nt}$ in samples 2 and 4 indicating the presence of the mutation in these samples. There is an additional band between 200 and 100 nt representing a PCR artefact. Samples I and 3 show only one band at 200 nt indicating lack of the mutation. 


\section{DISCUSSION}

Activating mutations in the $B R A F$ gene have been identified in many human cancers, with the highest frequency of mutations found in cutaneous melanomas (Brose et al, 2002; Davies et al, 2002; Goydos et al, 2005). In melanoma, these $B R A F$ mutations are found in two small regions of the kinase domain of the BRAF molecule. The predominant mutation occurs in exon 15 of the $B R A F$ gene with a single T-to-A substitution at nucleotide 1799, although a smaller number of mutations have also been found in a region of exon 11(Brose et al, 2002; Davies et al, 2002; Goydos et al, 2005). These mutations have been shown to be present in 66 to $80 \%$ of cutaneous melanomas and have also been detected in up to $82 \%$ of melanocytic nevi(Pollock et al, 2003). The mutation has also been reported in 22$40 \%$ of conjunctival melanomas and recently our group has identified this mutation in $48 \%$ of 19 iris melanomas (Gear et al, 2004; Spendlove et al, 2004; Henriquez et al, 2007). However, there have been several studies, in uveal melanoma including primary and metastatic choroidal and ciliary body melanomas and the BRAF mutation has only been identified in one case (Malaponte et al, 2006). Despite this apparent lack of the characteristic $B R A F$ mutation, inappropriate downstream MAPK component activation has been reported by Weber et al (2003) who failed to identify the BRAF mutation in 42 primary uveal melanoma but showed immunohistochemical staining for ERK in $86 \%$ of these cases. Similarly, Zuidervaart et al (2005) found constitutive activation of the MAPK pathway in 11 uveal melanoma cell lines and 19 primary tumours by performing western blot or immunohistochemistry for the various pathway components. However, an activating BRAF mutation was found in only one cell line. Using the more sensitive nested PCR approach we have identified the T1799A BRAF mutation in 4 of $20(20 \%)$ ciliary body melanomas and 11 of $30(40 \%)$ choroidal melanomas.

The majority of other studies have used some form of direct sequencing to identify this mutation (Cruz et al, 2003; Edmunds

Table I The number of mutated and non-mutated tumour areas in cases with the TI796A BRAF mutation

\begin{tabular}{lccc}
\hline \multicolumn{4}{c}{$\begin{array}{c}\text { Number of tumour areas } \\
\text { dissected }\end{array}$} \\
\hline $\begin{array}{l}\text { Mutation-positive } \\
\text { cases }\end{array}$ & $\begin{array}{c}\text { With the } \\
\text { BRAF } \\
\text { mutation }\end{array}$ & $\begin{array}{c}\text { Without the } \\
\text { BRAF } \\
\text { mutation }\end{array}$ & $\begin{array}{l}\text { Percentage of } \\
\text { areas with } \\
\text { mutation (\%) }\end{array}$ \\
\hline A & & & \\
B & 1 & 5 & 16.67 \\
C & 1 & 4 & 20.0 \\
D & 2 & 4 & 33.33 \\
E & 1 & 4 & 20.0 \\
F & 1 & 2 & 33.3 \\
Total & 2 & 2 & 50.0 \\
\hline
\end{tabular}

et al, 2003; Weber et al, 2003). Sequencing would not be able to detect mutant alleles present at low frequency because of somatic mosaicism. Although more sensitive techniques including the ligase detection assay and high amplicon melting PCR have been used to identify the $B R A F$ mutation in other tissues including cutaneous melanoma they have not been applied to uveal melanoma (Turner et al, 2005; Willmore-Payne et al, 2005). Recently, Maat et al (2008) detected the BRAF mutation in 6 of 45 uveal melanomas using the more sensitive technique of pyrophosphorolysis-activated polymerisation. In this technique a product is amplified only when the mutation is present even in the presence of tens of thousands of wild-type templates. The nested PCR approach described herein was developed using the SKmel-28 cell line, which is known to harbour the T1799A mutation. Consistent results were obtained using this technique and the mutation could also be detected at low frequency when DNA from SKmel-28 was mixed with wild-type DNA extracted from HFF. The robustness of the primers was established by thoroughly testing the annealing specificity of both wild type-specific and mutationspecific primers designed to anneal to the same site. By dilution of the mutated DNA it was estimated that this technique could detect at least one copy number of the mutation in 100 wild-type genes, and is therefore significantly more sensitive than techniques requiring direct sequencing.

The sensitivity of the PCR technique utilised would make it possible to identify mutant DNA in the presence of wild-type DNA. As separate samples from the same tumour did not always reveal the

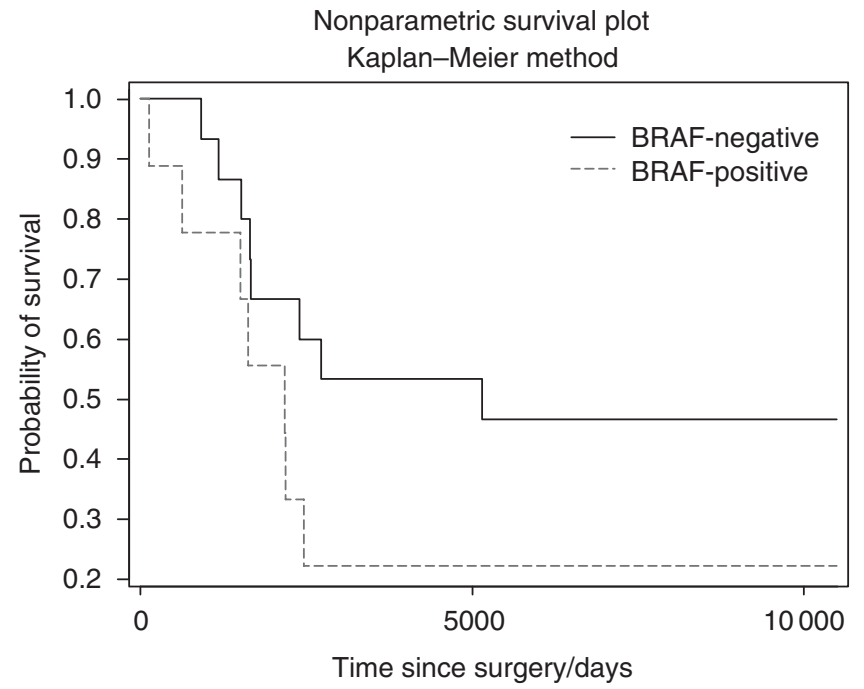

Figure 3 Kaplan-Meier survival curve showing the relationship between time as surgery and survival rate for patients with tumours with and without the BRAF mutation.

Table 2 Summary of clinical and pathological details for ciliary and choroidal melanomas with and without the BRAF mutation

\begin{tabular}{|c|c|c|c|c|c|c|c|}
\hline & $\begin{array}{c}\text { Average age } \\
\text { (range) }\end{array}$ & $\operatorname{Sex}(F: M)$ & $\begin{array}{l}\text { Average largest } \\
\text { tumour dimension } \\
\text { (range, } \mathrm{mm} \text { ) }\end{array}$ & $\begin{array}{l}\text { Cell type } \\
\text { (S:E:M) }\end{array}$ & $\begin{array}{c}\text { Vascular loops } \\
(\mathbf{Y : N )}\end{array}$ & $\begin{array}{c}\text { Metastases } \\
\text { Y:N:not known }\end{array}$ & $\begin{array}{c}\text { Follow-up } \\
\text { range (months) }\end{array}$ \\
\hline \multicolumn{8}{|l|}{ Ciliary Body } \\
\hline BRAF mutation & $33(16-48)$ & $9 F: 7 M$ & $15.5(10-20)$ & $3: 0: 1$ & $3: 1$ & $0: 3: 1$ & N/A \\
\hline BRAF wild type & $59(30-80)$ & $2 F: 2 M$ & $12.7(5-22)$ & $7: 0: 9$ & $7: 9$ & $1: 6: 9$ & N/A \\
\hline \multicolumn{8}{|l|}{ Choroid } \\
\hline BRAF mutation & $51(42-69)$ & $6 F: 5 M$ & $14.5(10-18)$ & 5:1:5 & $9: 2$ & 8:3:0 & $4-337$ \\
\hline BRAF wild type & $57(19-75)$ & | |F:8M & $14.7(8-23)$ & | $1: 0: 8$ & $12: 7$ & $8: 11: 0$ & $30-344$ \\
\hline
\end{tabular}


mutant band, this supports the theory that this mutation is only present in some of the tumour cells. Clonal heterogeneity, particularly morphological heterogeneity is well recognised in uveal melanoma (COMS, 1998) and the majority of tumours are composed of variable proportions of epithelioid and spindle-shaped cells. There have been few studies of cytogenetic heterogeneity in uveal melanoma. Sandinha et al (2006) described a heterogenous distribution of cells displaying monosomy three in uveal melanoma and Maat et al (2007) described areas of unmethylated and methylated RASSF1a within individual uveal melanomas. It is therefore plausible that the BRAF mutation could also be distributed heterogeneously. To address this problem we studied several separate tumour areas in 11 choroidal melanomas positive for the T1799A mutation. In six of the tumours positive for the BRAF mutation it was observed that the mutation was present in some areas of the tumour but not in others. However, it did not show any association with the cell types in the different areas.

Although the results of this study confirm that the BRAF mutation is heterogeneously distributed in uveal melanoma the frequency of this mutation still appears considerably lower than in cutaneous melanoma. This may be due to insufficient tumour sampling. Both cutaneous and uveal tumours share a common embryological origin from the neural crest but there are considerable differences between the cutaneous and uveal environment. For example, ultraviolet light is considered to be an important risk factor in cutaneous melanoma. It has also been suggested that exposure to ultraviolet light may be a key factor in melanomas with the T1799A point mutation(Thomas et al, 2006).
Previous research has also shown that the BRAF mutation frequency is lower in melanoma arising in sites protected from sun exposure compared with those from sun-exposed sites(Cohen et al, 2004). Although it is recognised that the BRAF mutation is not a UV-signature mutation, it has been suggested that it could still arise due to error-prone reduplication of UV-damaged DNA (Thomas et al, 2006). UV exposure is not considered a major factor in choroidal melanoma and this may in part explain the lower frequency of the mutation in the cases studied. An alternative explanation is that this $B R A F$ mutation is an infrequent event in uveal melanoma and the observed, inappropriate downstream activation of the MAPK component is due to genetic alterations in other components of this pathway.

In conclusion, we have shown that the $B R A F$ mutation is present in a proportion of posterior uveal melanomas and that within these tumours the distribution of this mutation is heterogeneous. This does not appear to carry any prognostic significance but may provide an explanation for the observed upregulation of the MAPK pathway in uveal melanoma.

\section{ACKNOWLEDGEMENTS}

This work was supported by the Royal College of Surgeons of Edinburgh, the Royal Blind Asylum and School and the Scottish National Institution for the War Blinded. We are grateful to $\mathrm{Mr}$ James Ralston for his technical expertise.

\section{REFERENCES}

Brose MS, Volpe P, Feldman M, Kumar M, Rishi I, Gerrero R, Einhorn E, Herlyn M, Minna J, Nicholson A, Roth JA, Albelda SM, Davies H, Cox C, Brignell G, Stephens P, Futreal A, Wooster R, Stratton MR, Weber BL (2002) BRAF and RAS mutations in human lung cancer and melanoma. Can Res 62: $6997-7000$

Cohen U, Goldenberg-Cohen N, Parrella P, Chowers I, Merbs SL, Pe'er J, Sidransky D (2003) Lack of BRAF mutation in primary uveal melanoma. Invest Ophthalmol Vis Sci 44: 2876-2878

Cohen Y, Rosenbaum E, Begum S, Goldenberg D, Esche C, Lavie O, Sidransky D, Westra WH (2004) Exon 15 BRAF mutations are uncommon in melanomas arising in nonsun-exposed sites. Clin Can Res 10: $3444-3447$

COMS (1998) Histopathologic characteristics of uveal melanomas in eyes enucleated from the Collaborative Ocular Melanoma Study. COMS report no. 6. Am J Ophthalmol 125: 745-766

Cruz F, Rubin BP, Wilson D, Town A, Schroeder A, Haley A, Bainbridge T, Heinrich MC, Corless CL (2003) Absence of BRAF and NRAS mutations in uveal melanoma. Can Res 63: $5761-5766$

Davies H, Bignell GR, Cox C, Stephens P, Edkins S, Clegg S, Teague J, Woffendin H, Garnett MJ, Bottomley W, Davies N, Dicks E, Ewing R, Floyd Y, Gray K, Hall S, Hawes R, Hughes J, Kosmidou V, Menzies A, Mould C, Parker A, Stevens C, Watt S, Hooper S, Wilson R, Jayatilake H, Gusterson B, Pritchard-Jones K, Maitland N, Chenevix-Trench G, Riggins GJ, Bigner DD, Palmieri G, Cossu A, Flanagan A, Nicholson A, Ho JWC, Leung SY, Yuen ST, Weber BL, Seiger HF, Darrow TL, Paterson H, Marais R, Marshall CJ, Wooster R, Stratton MR, Futreal A (2002) Mutations of the BRAF gene in human cancer. Nature 417: 949-954

Edmunds SC, Cree IA, Di Nicolantonio F, Hungerford JL, Hurren JS, Kelsell DP (2003) Absence of BRAF gene mutations in uveal melanomas in contrast to cutaneous melanomas. Br J Cancer 88: $1403-1405$

Gear H, Williams H, Kemp EG, Roberts F (2004) BRAF mutations in conjunctival melanoma. Invest Ophthalmol Vis Sci 45: 2484-2488

Goydos JS, Mann B, Kim HJ, Gabriel EM, Alsina J, Germino J, Weichung S, Gorski DH (2005) Detection of B-RAF and N-RAS mutations in human melanoma. J Am Coll Surg 200: $362-370$

Henriquez F, Janssen C, Kemp EG, Roberts F (2007) The T1799A BRAF mutation is present in iris melanoma. Invest Ophthalmol Vis Sci 48: $4897-4900$

Hogan MJ, Alvarado JA, Weddell JE (1971) Histology of the Human Eye: an Atlas and Textbook. WB Saunders Co: Philadelphia
Maat W, van der Velden PA, Out-Luiting C, Plug M, Dirks-Mulder A, Jager MJ (2007) Epigenetic inactivation of RASSF1a in uveal melanoma. Invest Ophthalmol Vis Sci 48: 486-490

Maat W, Kilic E, Luyten GPM, de Klein A, Jager MJ, Gruis NA, Van der Velden PA (2008) Pyrophosphorolysis detects B-RAF mutations in primary uveal melanoma. Invest Ophthalmol Vis Sci 49: $23-27$

Malaponte G, Libra M, Gangemi P, Bevelacqua V, Mangano K, D'Amico F, Mazzarino MC, Stivala F, McCubrey JA, Travali S (2006) Detection of BRAF gene mutation in primary chroidal melanoma tissue. Cancer Biol Ther 5: $225-227$

Pollock PM, Harper UL, Hansen KS, Yudt LM, Stark M, Robbins CM, Moses TY, Hostetter G, Wagner U, Kakereka J, Salem G, Pohida T, Heenan P, Duray P, Kallioniemi O, Hayward NK, Trent JM, Meltzer PS (2003) High frequency of BRAF mutations in nevi. Nat Genet 33: 19-20

Sandinha T, Farquharson M, McKay I, Roberts F (2006) Identification of heterogeneity for chromosome 3 copy number in choroidal melanoma: implications for cytogenetic screening. Invest Ophthalmol Vis Sci 47: $5177-5180$

Spendlove HE, Damato B, Humphreys J, Barker KT, Hiscott P, Houlston RS (2004) BRAF mutations are present in conjunctival but not uveal melanomas. Melanoma Res 14: 449-452

Thomas NE, Berwick M, Cordeiro-Stone M (2006) Could BRAF mutations in melanocytic lesioins arise from DNA damage induced by ultraviolet radiation? I Invest Dermatol 126: $1693-1696$

Turner DJ, Zirvi MA, Barany F, Elenitsas R, Seykora J (2005) BRAF V600E mutation in melanocytic lesions using the ligase detection reaction. J Cutan Pathol 32: 334-339

Weber A, Hengge UR, Urbanik D, Markwart A, Mirmohammadsaegh A, Reichel MB, Wittekind C, Wiedemann P, Tannapfel A (2003) Absence of mutations of the BRAF gene and constitutive activation of extracellular regulated kinase in malignant melanomas of the uvea. Lab Invest 83: $1771-1776$

Willmore-Payne C, Holden JA, Tripp S, Layfield LJ (2005) Human malignant melanoma: detection of BRAF- and c-kit activating mutations by high-resolution amplicon melting analysis. Hum Pathol 36: 486-493

Zuidervaart W, van Nieuwpoort F, Stark M, Dijkman R, Packer L, Borgstein A-M, Pavey S, van der Velden P, Out C, Jager MJ, Hayward NK, Gruis NA (2005) Activation of the MAPK pathway is a common event in uveal melanomas although it rarely occurs through mutation of BRAF or RAS. B J Cancer 92: 2032-2038 